\title{
SUMMARY RESPECTING THE PANEL PRESENTATION ON DEREGULATION OF THE NATURAL GAS INDUSTRY
}

This topic was presented by way of panel discussion. The members of the panel and their topics are as follows:

Panellist: Margaret A. Brown

Solicitor

TransCanada PipeLines Limited

Toronto, Ontario

Topic: This paper included a sketch of TransCanada's background, the necessity for long term gas supply and sales contracts, take-or-pay, the Topgas program, the government Agreement of October 31, 1985 on Natural Gas Markets and Prices and Conclusion.

Panellist: Sheila F. McAllister

General Counsel

Consolidated Natural Gas Limited

Calgary, Alberta

Topic: This paper reviewed contractual matters including the inception of direct sales by producers in Alberta and Saskatchewan to industrial consumers in Eastern Canada.

Panellist: Laurie F. Smith

Solicitor

Bennett Jones

Calgary, Alberta

Topic: This paper provided a review of the administrative hearings called by various regulatory tribunals in Canada since the October 31, 1985 Agreement and the various issues to be dealt with by such tribunals. It also reviewed legislative changes proposed as a result of the October 31, 1985 Agreement.

Panellist: Arnold R. (Bud) Madigan

Vice President and Assistant General Counsel

Enron Corp.

Omaha, Nebraska, and Houston, Texas

Topic: This paper reviewed the United States gas deregulation situation, and is published in full elsewhere in this Supplement.

Panellist: John Campion

Solicitor

Fasken \& Calvin

Toronto, Ontario

Topic: This paper reviewed the issues arising in Ontario from deregulation, and discussed the decision of the Ontario Energy Board in its Interim Contract Carriage Hearing. 